\title{
Exploration on Changes of English Teaching Philosophy under New Situation
}

\author{
WEN Lijun \\ Sichuan College of Architectural Technology, De Yang, Sichuan, 618000, China
}

\begin{abstract}
English education has been playing an important role in China's personnel training. As the navigation lights, educational philosophy is quietly changing with educators' long-term exploration and practice. As an important feature of its development and changes, career orientation under new situation makes educational patterns and focus more professional and social, reflecting the orientation of social talents cultivation. This work analyzed changes of English teaching philosophy from aspect of career orientation under new situation.
\end{abstract}

KEYWORDS: Career orientation; English teaching philosophy; changes

\section{INTRODUCTION}

With overwhelming English educational patterns and philosophy nowadays, English learning effects and training modes are highly concerned. English learning ability and knowledge structure can change students' way of thinking and help them form growth model with individual characteristics and cultural value. At this stage, English teaching philosophy includes the conventional modes focusing on humanized teaching and the fresh ones emphasizing on personalities. The excess diversities of English teaching philosophy cannot guarantee its applicability, feasibility and effectiveness. But it undoubtedly reflects the pursuit and expectations of educators and the society. Conventional English education should be improved to be more scientific and efficient, extracting existing theory and experiences as well as combining with needs of society.

\section{PROBLEMS OF EXISTING ENGLISH TEACHING PHILOSOPHY}

\subsection{False and vague English teaching philosophy}

English teaching accounts for a large proportion in China's compulsory and extracurricular education. Non-native language learning is highly emphasized and considered essential for adapting to society. All groups including students, teachers and parents are making efforts. At present, China's English teaching patterns are various. Both compulsory courses and professional English training ones uphold sharp or moderate teaching philosophy. These philosophies from conscious levels reflect educators' values of English knowledge transfer and personnel training; meanwhile, they are actually reflected in learners' cognitive effects and training feedback. With continuous teaching reform, English teaching philosophies are also constantly upgrading. However, the philosophy bubble hiding in the excellent situation should be noted. Some defective teaching philosophies exist in advanced ones. The majority of them are vague contents, lacking strong theoretical basis and reliable practical basis. They are unable to achieve desired results and even difficult to be practiced. They are often mixed with seemingly glamorous alien concepts or so-called popular elements. Besides, with some educators' unreasonable and irresponsible interpretations, they become impractical castles in the air, unable to play a substantial role for English education.

\subsection{Blind and impatient innovation of teaching philosophy}

Although the results of English teaching are mostly evaluated by exams, proficiency tests and other forms, theoretical and empirical studies of English teaching philosophy has never stopped. Based on years of teaching experience, teaching achievements and students' feedbacks, teachers have aggregated theoretical text and working methods. It reflects the development process of China's English education as well as the practical needs and expectations of society. It is a true portrayal that social development 
promotes educational progress. Annually published and applied English teaching philosophies are emerging endlessly in eye-catching packaging. Some educational institutions have put forward a variety of socialized English teaching and quick education, to attract the interest of students and parents. It caters to parents' needs of individualized training, but the actual effect is not significant. However, these institutions themselves have obtained staggering profits. This phenomenon is clearly contrary to the original intention of English education, difficult to train talents with higher English quality and personal style. In addition, English education of regular schools has seen bottlenecks. Stable teaching contents and class forms present some limitations. More teachers are willing to use previous experiences or existing theoretical results for conservative improvements of teaching methods, making teaching reform little success. Besides, some young teachers with advanced concepts and information resources lack of practical experience, difficult to adapt to the real English learning and teaching environment. Therefore, to innovate English teaching philosophy, educators should conduct robust and viable attempts based on full practice. They should look up at the stars while still get down to earth.

\subsection{Difficult practice of English teaching philosophy}

As pilots of various teaching activities, teaching philosophy has far-reaching significance and great value. Teachers struggling in the teaching line, colleges undertaking major social responsibilities as well as numerous social institutions are exploring more effective and targeted ideas and methods in practical work. The easiest and most fundamental way to evaluate a concept is to put it into practice, whether it achieves desired effect, gets good feedback and has space to improve and develop. It is also true for English teaching philosophy. Cooperation of teachers and students in class, assessment of teaching effect, as well as long-term achievements can well judge whether the idea is advanced. However, some so-called advanced teaching philosophies still remain in writing articles or slogans, having few opportunities for classroom practice. And they lack rigor recording and measurement even when practiced. Meanwhile, teachers ignore these advanced teaching philosophies and students know nothing more. This situation makes it difficult to practice teaching philosophy. The role and effectiveness of education reform become impossible. Objectively speaking, as fresh stuff in class, some excellent English teaching philosophies lack recognition and acceptance, vulnerable to exclusion and shock. Teachers should take the initiative to accept these new ideas and introduce them to students and courses. Thus, the first step of teaching reform can be taken. Moreover, in order to visually evaluate English teaching philosophies, teachers can record data in specific practical process such as completed progress of syllabus, students' acceptance of curriculum and students' English scores. Therefore, at the end of practical period, these data can be analyzed and compared. Old and new teaching methods can be accepted or rejected as well as perfected.

\section{CHANGING DIRECTION OF ENGLISH TEACHING PHILOSOPHY UNDER CAREER ORIENTATION}

\subsection{Early adaptation to students' career planning}

Undoubtedly, student's daily learning and long-term studies will eventually be transformed into practical productive forces. Long-term knowledge accumulation is necessary quantitative process before young people play social role. During this process, they develop basic cognitive abilities, characteristics and personal values, which will also greatly affect their adulthood career and social life. At this stage, common English education models are class teaching in schools and test evaluation of fixed forms, while professional English teaching linked to occupations appears in undergraduate or college education. And most students will join the job tide to find suitable occupations after only two or three years of professional training. But seen from practical results, industrial professional English cannot be easily mastered in merely two or three years. Also students' adaptation and acceptance process is longer than that. Therefore, career planning concerning English should be advanced as soon as possible. When students have formed certain career planning, schools and teachers should be proactive for individualized training and emphasized professional English teaching. This kind of English teaching can be achieved through various forms such as second class and visiting practice. With purpose of career planning, these forms can enrich students' English courses, as well as maintain their enthusiasm for learning and career planning. Despite the flourishing situation in changes of English teaching philosophy, they all have distinct characteristics of individualized teaching. Such a big trend can promote career-oriented English teaching and meet students' individual needs and training programs, achieving a deeper level of professional personnel training.

\subsection{Initiative to provide career-oriented professional advice}

As an international language generally accepted and utilized, English has the actual significance far exceeding the scope of language. It covers functions 
of international exchanges and tool language of national culture and science. Most students in China have taken compulsory English education or higher level professional English education, with some conditionally abroad study. Various forms of language learning not only improve students' English proficiency from basic level to application level, but also allow them to try the vivid and profound effect of English as language. In fact, English applied in trades and occupations is far different from which students are universally learning. They often involve specialized vocabulary, terminology and abbreviations, the theme of which is closer to certain professional levels. Students are required to not only achieve cognitive level, but also reach skilled and flexible utilization levels in future jobs. Thus, they can perform as professional persons to accomplish their work and duties. In terms of schools, they should timely convey career concepts and knowledge as well as rational career choice guide in basic English education. Consequently, students can form simple career planning as early as possible and purposely adjust learning and personal development programs. In terms of teachers, they can try some knowledge expansion and set career English section, providing students with English background knowledge of different industries. When students have questions and needs in this regard, teachers and schools can conduct flexible exchanges and guidance, and even contact parents when necessary for deeper educational programs improvement. It ensures that each student's initial career ideas are protected and valued.

\subsection{Further emphasis on practicality of English teaching}

Although English evaluation proportion decreases according to college entrance examination reform policy, its practical role cannot be underestimated. English is a usual project in personnel training, but with a fundamental role. Meanwhile, English is a necessary practical tool in students' future career and higher level professional positions demand for higher level English. It also explains why parents pay such attention to their children's English training and promotion. Therefore, teaching philosophy reform should emphasize practicality, which is the basic direction of its changes. Its practicality should be highlighted designedly from multi-angle and multilevel, so that some precious English teaching philosophy can be effectively translated into reality.
Under career orientation, schools should maintain original fundamental teaching and valuable experience and conduct adaptation from shapes and forms, enhancing added value of course knowledge. Thus, students will get comprehensive and real career-related English knowledge as well as speaking and writing skills. Schools can boldly extend classroom to professional areas, such as factories, workshops and technical departments, to help students get intuitive understanding of their interested industries. It will also encourage them to take the initiative to explore relevant expertise and English knowledge. In addition, teachers can add scene setting, scenario simulation and other sectors to conventional classes. It helps to enrich teaching content, liberate students' thinking, encouraging them to break the mindset and try flexible, practical ways. Meanwhile, schools and teachers should also note students' accumulation of professional knowledge and provide rich learning resources and career opportunities for them. Thus, students' professional ideas and social attitudes will be developed, and their ability level will be quickly optimized to meet higher social needs.

\section{CONCLUSIONS}

From campus to workplace, students will get new awareness and be tempered in the fierce job competition. And they need to accept adequate training of vocational concepts at campus. Also, English teaching activities and related teaching methods and philosophy need to continually move closer to the goal of professional personnel training. Thus, a smooth transition between learning and work will be ensured to provide professionals for the society.

\section{REFERENCES}

[1] Liu Lin Lin. Reform of Project Management Course Teaching on Career-orientation base. User World .2014 (7): 209-209.

[2] Li Chengfeng. An idea about English Education Philosophy: Teaching Methods and Devoted Love. Secondary Education Counseling: Teacher Education. 2014 (5): 5-5.

[3] Zhang Yuchun. Exploration on Countermeasures of English Education Philosophy Innovational Reform. Science Education Article Collects .2014 (8): 120-121. 